\title{
Students' Background Diversity, Their VAK Learning Style and Lectures Teaching Strategies
}

\author{
Aulia Putri \\ Faculty of Teacher Training and Education \\ University of Riau Kepulauan (UNRIKA) \\ Batam, Indonesia \\ email: auliaputri1983@yahoo.com
}

\begin{abstract}
As it is seen everywhere, many learners are interested in studying English-whether it is because they want to or because they need to. Those learners come from different countries with different races, cultures, occupations, and economic levels. Therefore, the researcher is interested to analyze about how lecturers as the educators treat the students in the class, especially in University of Riau Kepulauan, Batam, Indonesia. The aim of this study is to explore how the lecturers see the diverse background of the students as an additional value in teaching them with the given material. As a result, the lecturers need to have some teaching strategies to maintain a well-organized class. Furthermore, the classes in this campus are held in evening session and most of the students are workers. Based on these facts, there are some challenges that are faced by the lecturers to have a cooperative teaching learning process. Moreover, the lecturers also need to be creative in delivering the teaching materials so that the students can understand more in such circumstances. At last, this study also analyzes what kind of learning strategies that their students have. Particularly, the researcher wants to find out what are the students VAK learning styles; which stands for Visual, Audio, and Kinesthetic Learning Styles. Do they prefer to study by using visual material, more on listening, or more in practice part? This is also part of lecturers' challenge whether do lecturers provide specific material or certain strategies to support these students' learning styles or not.
\end{abstract} strategies

Keywords-diversity; VAK learning styles; teaching

\section{INTRODUCTION}

University of Riau Kepulauan is a private university located in Batam Island, Indonesia. Geographically, Batam is a very strategic island placed in the border of the country. It is only 45 minutes distance from Singapore by ferry. As a transit island, many people love to stay in Batam and choose to be its society. As a result, this condition made Batam as a pluralism city. Much diversity can be seen in this city. For instance, it can be found people from different ethnic groups, different religions, and different jobs. Based on these facts, the researcher is interested in analyzing students' background diversity in University of Riau Kepulauan.

After knowing the diversity of the students, the researcher is interested to know the learning styles of the students; which is also one kind of diversity of the students. Do they love to learn visually, audibly, or kinesthetically?
Do they prefer to study by using visual material, more on listening, or more in practice part? At last, by looking this condition, the researcher also wants to figure out whether the lecturers pay attentions to this diversity or not. Does this condition mean something to the lecturers? Does this influence their teaching strategies in the class or not?

\section{A. Diversity}

\section{REVIEW OF RELATED THEORIES}

Students have much uniqueness where one will vary from the other; which can be called as students' diversity. Talking about diversity, there are some aspects that can be categorized as diversity. Some will see from students' level of motivation, their attitude about teaching and learning (Felder and Brent, 2005). While, Jeannin (2013: 7) states that students has diversity in age, work experience, race, gender, learning style, language proficiency, prior knowledge, maturity, and learning abilities. These diversities can affect students' learning experience in the classroom. Moreover Eaves (2009) in Jeannin (2013: 8) mentions that students who have different cultural backgrounds are comfortable with certain teaching practices.

Another diversity that also becomes one interesting topic to discuss is cultural and linguistic diversity (CALD). It focuses not only to the cultural backgrounds of the students but also the different levels of their linguistic ability. It is about how to combine both differences and produce a certain approach in teaching. (Moloney, 2016)

\section{B. VAK Learning Styles}

According to Pritchard (2009: 51), learning styles are defined in many ways such as: specific way in which one learns; -how preferred learning best for a person to think, the process of information and the demonstration of learning; the preferred way for a person to acquire knowledge and skills; habits, strategies, or usual mental attitude about learning, especially learning education, shown by people.

Furthermore, Pritchard (2009: 44-45) also explains that there are three kinds of specific learning styles, namely: 1. Visual learning style

In visual learning style, students prefer to learn by watching. Students with this learning style choose the 
information displayed in the form of charts, graphs, maps or posters. Another distinctive feature of visual learners is they frequently use hand gestures to describe a situation or an object.

2. Auditory learning style

Auditory learners learn more while listening. They have a good auditory memory of discussions, lectures, interviews, and stories. Their tendency is they love something in order, repetitive and conclusions. When considering something, they like tilting their heads and often move their eyes.

3. Kinesthetic learning styles

Students with kinesthetic learning style like to learn from doing something or to practice it. They love physical activities, trips, and other practical lessons. Additionally, kinesthetic learners also difficult to remain silent and take breaks in class activities.

Moreover, Reid (2005) explains the benefits and disadvantages of the three learning styles described above.

a. visual learner

The students are good at receiving information and visual events and can image it. They apply visual strategies for recall information. In addition, students with a visual learning style enjoy the atmosphere of learning that involves visual and creative abilities. They can also see the whole picture when discussing or doing tasks and solving problems.

The weakness of students with a visual learning style is that they require more time to complete their tasks. These students are more interested in appearance than the real value-something that might hurt sometimes. Furthermore, they may not spend enough time or attention to detail.

b. auditory learners

The benefits obtained by the students, namely: they can receive information either from listening to the conversation or lecture, and absorb a lot of information from the radio. The other benefit is they can collate information and remember it by making a list. In the real world, they will be independent workers and reliable.

The weakness of the students with this kind of learning styles is they have to complete one task before beginning another task. Another tendency that can be a drawback as well is they only pay attention to a small portion of the information they can and do not get an overall picture of something they are working at. Other tendency is that they prefer to work alone rather than work in a group.

c. kinesthetic learner

The advantage owned by the students with this learning style is they enjoy an active learning useful in assembling something or producing. They can show others how to do something. This is because they prefer practice rather than theory in learning something.

The weakness of kinesthetic learning style is a student may skip some of the information given orally. They are difficult to concentrate on writing task while sitting in the classroom. Besides, they do not like paying attention to detail, especially in written form.

\section{Teaching Strategies}

Concerning students' background diversity and different learning styles, inclusive teaching approach was promoted that adapts to students learning habits. Here, teachers should provide activities that are needed by the students. The key point is the feeling of inclusiveness that they have in certain activities. (Richard, et al, 2007 in Jeannin, 2013).

There are 14 teaching strategies compared by Wehrli and Nyquist (2003), i.e.: brainstorming, small group discussion, computer simulation, demonstration, game, independent study, large group discussion, lecture/presentation, role play, self-awareness exercise, direct patient contact, one-to-one, role modeling, and, standardized patient. Those strategies can be use by teachers in any kind of situation in the class. It depends on the class circumstances, total number of students, and lesson topic.

\section{METHOD}

This research is a qualitative research which presents the data in a descriptive way. The research questions are:

a. What kinds of background diversities do the students have?

b. What kinds of VAK learning styles do the students prefer?

c. What kinds of teaching strategies do the teachers apply in their classrooms?

A self-completion questionnaire was given for both the students and the teachers to know students' background diversities and teachers' teaching strategy. To know students' learning style, Reid's questionnaire was given.

The participants in this research are students and lecturers. There were 29 students in the second semester. The samples were taken by using purposive sampling technique. While, there were 6 English lecturers participated in answering self-completion questionnaire. Incidental sampling technique was used.

\section{FINDING AND DISCUSSION}

\section{A. Students' Background Diversity}

A self-completion questionnaire was given to 29 students of UNRIKA, Batam to find out the diversities. They were 9 males and 20 females. It was found that 10 students were Bataknese, 1 student was from Bengkulu, 2 students were Bugis, 2 students were Javanese, 5 students are Malay people, 2 are from Manado, 4 of them are Minangnese, 1 Nias, 1 Palembang, and 1 Sundanese. It can be concluded that the dominant ethnic was Bataknese even though the university is located in Riau Islands which the people are included to Malay ethnic. From the description 
given, it is known that the characteristics of Bataknese are straight to the point, firm, hard working people, and loud. It also gives a color to the class' nuance.

The next diversity is about their occupations. It was found that 15 students were working and others just focused on their study. It can be concluded that $51.72 \%$ were workers or it can be said that more than a half of the students were having extra hours to study after spending their day working. In this case, they need strong effort or motivation to study in the class; it can be internal or external motivation. As a matter of fact, the lecturers also need to think how to boost their students' mood to study as the external motivation for the students. It can be done through various teaching strategies applied by the lecturers.

\section{B. Students' VAK Learning Styles}

In order to know the learning preferences of UNRIKA students, Reid's (1987) Perceptual Learning Style Preference Questionnaire (PLSPQ) was used. This questionnaire was developed especially for foreign language learners. It is assesses preferred learning styles of the students; visual, auditory, and kinesthetic preferences. This questionnaire is chosen because it is easy, simple and selfscoring. PLSPQ consists of 15 questions categorized into visual, auditory, kinesthetic learning styles. Subjects are requested to answer the statements whether they agree or disagree with the scale 1 to 5 . Scale 1 is strongly disagree, 2 is disagree, 3 is undecided, 4 is agree and 5 is strongly agree.

The 29 students as participants consist of 9 males and 20 females. They were students of English Education Department, University of Riau Kepulauan. They were between 18 to 33 years of age. Fifteen questions with 5 options were given out to the students. From the data analysis, it was specified that about $27.59 \%$ of the students chose visual learning style, $10.35 \%$ of the students preferred auditory learning style, $20.69 \%$ of the students preferred kinesthetic learning style, while the rest about $20.69 \%$ were mix between visual and auditory learning styles, and others $20.69 \%$ had VAK learning styles. Based on that finding, it can be concluded that the common learning style among students of UNRIKA Batam was visual. Seeing the variety of learning styles that the students have, the lecturers and the students need to find the best teaching and learning approaches. It can be guidance for the lecturers to know certain teaching strategies that fit their students' need as well. For the students, they can increase their self-awareness in finding the best way to enhance their learning perceptive.

\section{Lecturers' Teaching Strategies}

The lecturers were also given a self-completion questionnaire to know about their teaching strategies in the class. There were 6 lecturers participated in this research, they were taken by using incidental sampling technique. From the questionnaire, it was found that the lecturers were using different teaching strategies that they found effective in their classes. Below is the explanation of each teaching strategy used by the lecturers.

Lecturer 1 thinks that what motivates students in learning is when the lecturer gives appreciation to the students that make them feels better. He hopes that at the end of the class the students would be able to master the material. In doing so, the lecturer does some teaching strategies that he thinks might be useful. One pedagogical method that he applies is EGRA (Exposure, Generalization, Reinforcement, Application) method. He hopes that he can transfer knowledge by using this method. It can be done by having a good communication system and with the students and also good class management. The strategy that he wants to apply in the future is by empowering the students. To get the best result, he still explores himself to find the suitable teaching strategy for the class.

The second lecturer believes that every student has his or her own motivation learning. The key is just to let the students to find their own way. When the class is over, she hopes that the class has a good cooperation and unity to the lecturers, others and of course themselves. In teaching, she considers that every student is special; therefore she applies different teaching strategies to teach them. She applies selflearning and cooperation in the class. She trusts them to learn by themselves to solve problems they meet. On the other hand, she also combines materials with students' learning strategies. The other strategy that she wants to use in the future is by making all students interact to society directly; so not only teaching and learning about theories.

Lecturer 3 suggests the students to find their own internal motivation. He believes that his students learn best when they are being challenged. He prefers to provide a better atmosphere for a classroom environment. In teaching learning process, he usually uses teacher-centered and student-centered. Specifically, he chooses Communicative Language Teaching. In the future, he is interested in applying Dogme Language Teaching. It focuses on conversational communication among learners and teacher. He thinks that he must use many creative methods in teaching. To ensure that the students make what they learn as part of themselves, he assesses the students by using portfolio or formative assessments.

The forth lecturer thinks that students will be motivated when they understand what are the learning goals and objectives that they have to achieve. She also keeps reminding her students to see their future as their targets. She believes when students happy they can learn easily. It can be done by communicating harmoniously to the students. In teaching-learning process, she implies constructivism learning theory. In the application, she usually uses problem-based learning, project-based learning, and jigsaw technique. In the process, she gives direct feedback and reward to the students. According to her, assessing does not mean only focus to the academic performance. She finds sometimes it is challenging to anticipate the decrement of social and positive norms performed by the students. 
Lecturer 5 believes that by giving the students some tasks, they can comprehend the materials given related to the topic discussed. She also thinks that students do not need to memorize the materials but only to understand them. She knows that the students learn when they can apply the knowledge to the next related materials. Some teaching methods that she uses in the classroom are lecture, individual performance, group presentation, etc. It depends on the improvement of the students' comprehension about the material. She believes every teaching technique is useful as long as the lecturers are serious and active in teaching. In assessing the students, she learns that teaching is not only about giving material to the students but also about how they are interested in.

The last lecturer believes that appropriate teaching strategies will motivate the students. At the end of the course, she hopes the students can have not only the materials given but also soft skills. She applies creative tutorial in the class. It is also supported by having group presentation or discussion. She is interested to apply lesson study strategy in the next term. In the process of teachinglearning, she figures out that she needs to improve the methods and strategies.

\section{CONCLUSION}

From the above explanation, it can be concluded that every lecturer attempts to find the best teaching strategies to make his or her students comprehend the material. It is not only the strategies that the lecturers

\section{References}

[1] Felder, Richard M. and Brent, Rebecca. Understanding Student Differences. Journal of Engineering Education, 94 (1), 57-72. 2005. Retrieved on March 15, 2017 at http://www4.ncsu.edu/unity/lockers/users/f/felder/p ublic/Papers/Understanding_Differences.pdf

[2] Jeannin, Loise. Students' Perception of Diversity in an International Classroom. Higher Learning Research Communications, 3 (4), 6-23. 2013, Retrieved on April $1^{\text {st }}, 2017$ at http://dx.doi.org/10.18870/hlrc/v3i4.165

[3] Moloney, Robyn and Saltmarsh, David. 'Knowing Your Students' in the Culturally and Linguistically Diverse Classroom. Australian Journal of Teacher Education, 41. (4). 2006. Retrieved on April $1^{\text {st }}$, 2017 at http://dx.doi.org/10/14221/ajte.2016v4n4.5

[4] Pritchard, Alan. Ways of Learning: Learning Theories and Learning Styles in Classroom. New York: Routledge. 2009

[5] Reid, Gavin. Learning Styles and Inclusion. London: Paul Chapman. 2005

[7] Reid, J.M. The Learning Style Preference of ESL Students. TESOL Quarterly, 21 (1), 87-111. 1987

[8] Wehrli, G. and Nyquist, J.G. Creating an Educational Curriculum for Learners at Any Level. AABB Conference. 2003 